\title{
CONSERVATION
}

\section{Invading the natural marine substrates: a case study with invertebrates in South Brazil}

\author{
Janaína Bumbeer ${ }^{1,2} \&$ Rosana Moreira da Rocha ${ }^{3}$
}

\author{
'Corresponding author. Programa de Pós-Graduação em Ecologia e Conservação, Universidade Federal do Paraná. \\ Caixa Postal 19031, 81531-980 Curitiba, PR, Brazil. \\ ${ }^{2}$ Associação MarBrasil. Avenida Beira-Mar, Caixa Postal 48, 83255-976 Pontal do Paraná, PR, Brazil. \\ E-mail: janaina@marbrasil.org \\ ${ }^{3}$ Departamento de Zoologia, Universidade Federal do Paraná. Caixa Postal 19020, 81531-980 Curitiba, PR, Brazil.
}

\begin{abstract}
The number of biological invasions has grown dramatically in recent decades, as well as the world's human population and coastal development. Anthropogenic habitats, such as pier pilings and break waters, have been constantly added to marine environment, usually concentrated in estuarine areas. These habitats are focal points for marine invasions, but relatively little is known about the spread of non-indigenous species (NIS) to nearby natural habitats. This study aimed to determine the extent to which NIS have spread to natural substrates both inside estuarine areas and in the adjacent open sea. We conducted a field survey and a literature review, which have been critically discussed and validated. The updated NIS list of benthic invertebrates comprises 19 species: Ascidiacea (5), Cirripedia (5), Cnidaria (3), Mollusca (3), Polychaeta (1), Decapoda (1), and Echinodermata (1). Our results suggested substantial spread of non-indigenous species into natural substrates. Altogether, 18 and 16 NIS were recorded in artificial and natural substrata, both representing $13 \%$ of the total species in each habitat. The percentage of NIS was more pronounced in the estuarine areas, $17.6 \%$ in artificial habitats and $18.6 \%$ in natural ones. Programs developed for the monitoring of marine invasion have to broaden their focus including natural areas adjacent to ports and marinas, to follow the spread and impact of NIS on these areas.
\end{abstract}

KEY WORDS. Anthropogenic habitats; natural habitats; checklist; invertebrates; marine bioinvasion.

Non-indigenous species (NIS) are rapidly changing our marine ecosystems. The number of biological invasions has grown dramatically in recent decades, as well as the world's human population and coastal development. Anthropogenic habitats, such as pier pilings, break waters, and floating docks, have been constantly added to marine environments and represent novel substrata for marine communities (CONNell 2001, Bulleri \& Chapman 2010). These man-made structures, which are typically associated to vectors of NIS such as shipping and aquaculture, have long been known to be focal points for marine invasions and can act as stepping stones for NIS spread (Tyrell \& Byers 2007, Glasby et al. 2007, Ruiz et al. 2009, SEEBENs et al. 2013). Such anthropogenic habitats and activities are usually concentrated in sheltered coastal areas, such as bays and estuaries, which act as hubs of bioinvasion (Ruiz et al. 1997, WAsson et al. 2005, Preisler et al. 2009). For this reason, most studies of NIS take place in harbors, where most invasive species are expected to be found.

The disparity in number of NIS between artificial vs. natural substrata and bays vs. outer coasts is well documented (LAMBERT \&
Lambert 2003, Glasby et al. 2007, Preisler et al. 2009, Ruiz et al. 2009, DAfForn et al. 2012). However, NIS may spread out from harbors, ports or other sources, and the extent of the escape from these entry points to other suitable habitats has been evaluated at very few regions (SimKANim et al. 2012, Airoldi et al. 2015). This gap of understanding is still more remarkable in developing countries, where there are only a few published studies on invasion ecology (PYšEK et al. 2008, NuñEz \& PAuCHARd 2010). To our knowledge there is only one study in the Atlantic Southwest, in Argentina, regarding the distribution of NIS in estuarine areas and open coast (see PREISLER et al. 2009), and one study comparing the NIS in artificial and natural substrata, in Ilha Grande Bay, Brazil (IGNACIO et al. 2010). However, a comprehensive regional survey of NIS in hard substrate communities considering artificial and natural substrata in both estuarine and coastal area, has not been published yet.

The southern Brazilian state of Paraná has a relatively short coast ( $100 \mathrm{~km}$ long). However, it harbors two estuaries, Guaratuba Bay and the Paranaguá Estuarine Complex (PEC), which increase the coast perimeter and influence the marine adjacent 
region. The PEC is among the largest estuaries in Brazil, and of considerable economic and ecological importance to the entire southern region of the country. Despite being one of the most preserved Brazilian coastal environments, even ranked as a World Heritage site (UNESCO 2014), it is subjected to many anthropogenic impacts that may favor bioinvasions, such as port-related industries and activities, tourism and aquaculture. Previous studies have revealed that PEC is indeed an entrance for NIS in the state (Neves et al. 2007, Neves \& Rocha 2008, CANGussu et al. 2010). Such studies have focused on anthropogenic habitats in estuarine areas and there is a paucity of studies about NIS on natural substrata in this region. Thus, this study aimed to determine the extent to which NIS have spread to adjacent natural substrates both inside estuarine areas and in the adjacent open coast. An updated list of benthic marine non-native fauna in the Paraná is also provided, which have been critically discussed and validated (Appendix $\mathrm{S}^{1}{ }^{1}$ ).

\section{MATERIAL AND METHODS}

The state of Paraná has a continental shelf (CS) between 175 and $190 \mathrm{~km}$ wide, predominantly covered by sand, mud and clay, except for the few natural hard substrates that border the islands. The main coastal islands are Figueira, Mel, Galheta, Currais and Itacolomis, from north to south. Paraná coast also has two large estuaries: The Paranaguá Estuarine Complex (PEC), located at the northern limit of the Paraná coast and one of the largest estuaries in Brazil, with a total surface area of $\sim 612 \mathrm{~km}^{2}$, and Guaratuba Bay (GB), located south, with $\sim 50 \mathrm{~km}^{2}$ of surface area (LaNA et al. 2001).

Surveys were carried out in both artificial and natural substrata within the PEC and in the inner continental shelf off Paraná (Fig. 1). Sites with different depths and wave exposures were sampled in order to include a wide variety of environmental features. Inside PEC, a total of seven sites were sampled: Cobras island, Filhote island, Bananas islands, Baleia rock, Vedado rock and the artificial substrata of Techint pier and Ponta do Poço marina. At the inner continental shelf, five sites were sampled: Mel island, Galheta island, Currais archipelago and two sites of artificial reefs (ARs) (concrete blocks placed in the seabed to provide new environments for encrusting communities).

The sites were sampled by SCUBA diving at least twice each between July 2012 and January 2015, with a total of 48 scuba dives. The largest sampling effort was in the sites with a lack of previous studies, i.e., open sea areas and natural substrata. Most of the sites were surveyed both along shallower (around 2-4 m) and deeper (5-8 m) $20 \mathrm{~m}$ long transects (Appendix 1). Artificial reef sites were surveyed at $\sim 13$ and $\sim 18 \mathrm{~m}$, depending on their deployment depth. During those dives, specimens were photographed and collected for identification. Upon collection, samples were treated with a menthol solution in seawater for relaxation of the fauna and subsequently fixed in $4 \%$ formalin for taxonomical study by specialists.

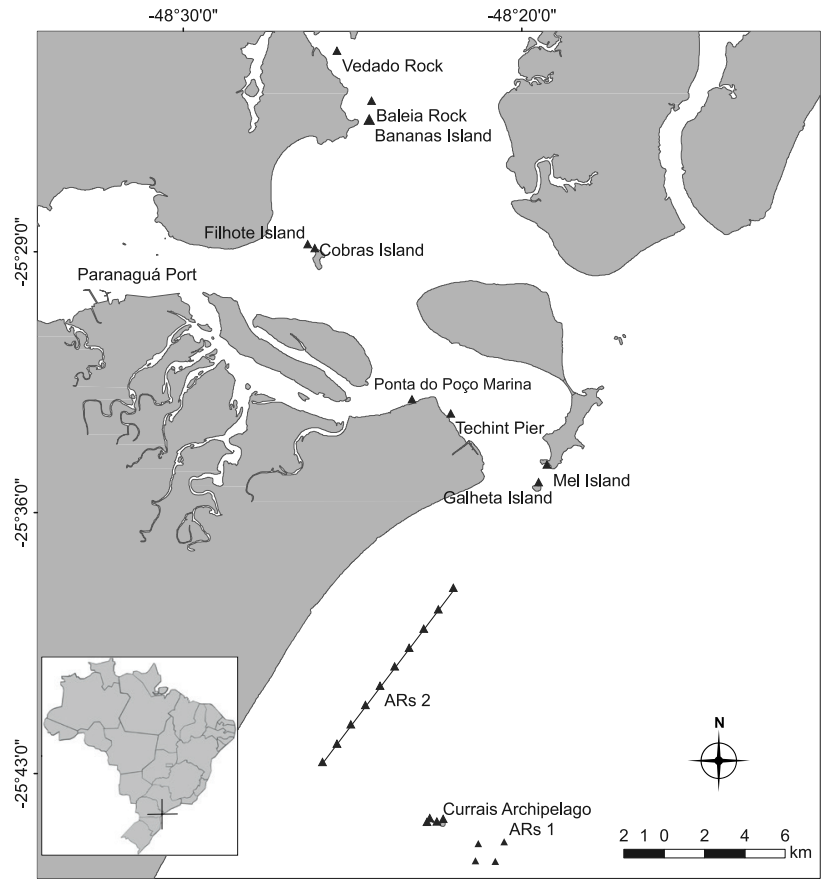

Figure 1. Location of field survey sites, state of Paraná, southern Brazil.

A search of the literature was also conducted to review all records of benthic marine fauna in Paraná. This search included journal articles, and two official lists of introduced species, one regional (IAP 2015) and another national (Lopes 2009). Furthermore, specialists were contacted to complement the available information and confirm some records.

Non-indigenous species were classified as proposed by the Brazilian Ministry of Environment (LOPEs 2009): Detected - when the NIS was detected in natural environment, but without further increase of its abundance and/or dispersion; Established - when the NIS was detected recurrently, but with no apparent ecological or socioeconomic impacts; Invasive - when the established species interfere with the survival of other species, or when the species causes measurable socio-economic or human health impacts. A species recorded in at most two sites, and only once per site, was considered detected. A species recorded in three sites or more, and at least two times in at any given sampling site, was considered established. Established species with records of ecological or economic impact were considered invasive.

\section{RESULTS}

Considering the new surveys, and all the information from literature and experts, we found 19 NIS in hard-substrate communities in Paraná: Ascidiacea (5), Cirripedia (5), Cnidaria (3), Mollusca (3), Decapoda (1), Echinodermata (1) and Poly-

${ }^{1}$ Available as Online Supplementary Material with the HTML version of the article at http://www.scielo.br/zool 
Table 1. List of marine benthic non-native species of Paraná, south Brazil.

\begin{tabular}{|c|c|c|c|c|}
\hline Taxa & Status & Occurrence & Habitat & References \\
\hline \multicolumn{5}{|l|}{ Ascidiacea } \\
\hline Ascidia sydneiensis Stimpson, 1885 * & $\mathrm{D}$ & CS & $\mathrm{RS}, \mathrm{AR}$ & Rocha \& Kremer (2005) \\
\hline Ascidia tenue (Monniot, 1983) & $\mathrm{D}$ & CS & AR & Bumbeer \& Rocha (2012) \\
\hline Clavelina oblonga Herdman, 1880 * & $\mathrm{E}$ & CEP, CS & $\mathrm{RS}, \mathrm{AR}$ & Rocha \& Kremer (2005), Cangussu et al. (2010) \\
\hline Sidneioides peregrinus Kremer, Metri \& Rocha, 2011 & $\mathrm{D}$ & CEP & RS & KREMER et al. (2011) \\
\hline Styela plicata (Lesueur, 1823)* & 1 & CEP, GB, CS & RS, PM & Rocha \& Kremer (2005), ARRUDA (personal communication) \\
\hline \multicolumn{5}{|l|}{ Cirripedia } \\
\hline Amphibalanus amphitrite Darwin, 1854 * & $\mathrm{E}$ & CEP, CS & RS, PM, AR & Neves et al. (2007), Cangussu et al. (2010), Bumbeer \& Rocha (2012), KLôH et al. (2013) \\
\hline Amphibalanus reticulatus (Utinomi, 1967)* & $\mathrm{E}$ & CEP, GB, CS & RS, PM, AR & Neves et al. (2007), Cangussu et al. (2010), Bumbeer \& Rocha (2012), KLôH et al. (2013) \\
\hline Balanus trigonus Darwin, $1854^{*}$ & $\mathrm{D}$ & CEP, CS & PM, AR & Cangussu et al. (2010), Bumbeer \& Rocha (2012) \\
\hline Megabalanus coccopoma Darwin, 1854 * & $\mathrm{E}$ & CEP, GB, CS & $\mathrm{RS}, \mathrm{PM}, \mathrm{AR}$ & Cangussu et al. (2010), Bumbeer \& Rocha (2012), KLôH et al. (2013) \\
\hline Striatobalanus amarylis Darwin, 1854 * & $\mathrm{E}$ & CEP, CS & RS, PM, AR & Neves et al. (2007), Cangussu et al. (2010), Carlton et al. (2011), Bumbeer \& Rocha (2012) \\
\hline \multicolumn{5}{|l|}{ Cnidaria } \\
\hline Carijoa riisei (Duchassaing \& Michelotti, 1860) * & E & CEP, CS & RS, PM, AR & Cangussu et al. (2010), Bumbeer \& Rocha (2012) \\
\hline Garveia franciscana Torrey, 1902 * & $\mathrm{E}$ & CEP, CS & RS, PM, AR & Neves et al. (2007), Cangussu et al. (2010), Bumbeer \& Rocha (2012) \\
\hline Stragulum bicolor Van Ofwegen \& Haddad, 2011* & $\mathrm{E}$ & CEP, GB, CS & RS, PM & van Ofwecen \& Haddad (2011), Bumbeer \& Rocha (2012), Altvater \& Coutinho (2015) \\
\hline \multicolumn{5}{|l|}{ Mollusca } \\
\hline Isognomon bicolor (Adams, 1845) & $\mathrm{E}$ & CEP, GB, CS & RS & LOPES (2009) \\
\hline Myoforceps aristatus (Dillwyn, 1817) * & I & CEP, CS & RS, PM, AR & \\
\hline Perna perna (Linnaeus, 1758) * & 1 & CEP, GB & RS, PM, AS & LOPES (2009) \\
\hline \multicolumn{5}{|l|}{ Decapoda } \\
\hline Charybdis hellerii (A. Milne-Edwards, 1867)* & 1 & CEP, CS & RS, SB, M, AS & FriGotto \& Serafim (2007), TCP (2010) \\
\hline \multicolumn{5}{|l|}{ Echinodermata } \\
\hline Ophiothela mirabilis Verrill, 1867 * & 1 & CEP, CS & RS, PM, AR & HeNDLer et al. (2012) \\
\hline \multicolumn{5}{|l|}{ Polychaeta } \\
\hline Polydora cornuta Bosc, 1802 & $\mathrm{D}$ & CEP & SB, PM & RadASHEVsky (2004), Neves et al. (2007), Lopes (2009) \\
\hline
\end{tabular}

chaeta (1) (Table 1, Appendix S1 ${ }^{1}$ ). Of these, five are invasive in Paraná, nine are established and five have been detected but it is not known if they have established sustainable populations (Appendix 2). A total of 174 invertebrates species were recorded, thus the NIS represents $11 \%$ of the fauna surveyed. We found 143 and 127 species in artificial and natural substrata, respectively, and 112 and 152 species in bays and open sea, respectively.

Altogether, 18 and 16 NIS were recorded in artificial and natural substrata, both representing $13 \%$ of the species in the respective habitats. Three species occurred only in artificial substrata, the ascidian Ascidia tenue (Monniot, 1983), the barnacle Balanus trigonus Darwin, 1854 and the polychaete Polydora cornuta Bosc, 1802. One NIS was exclusively found on natural substrata, the ascidian Sidneioides peregrinus Kremer, Metri \& Rocha, 2011 (Table 1). Four NIS are reported here for the first time in natural substrata in the region, the octocoral Carijoa riisei (Duchassaing \& Michelotti, 1860), the hydrozoan Garveia franciscana Torrey, 1902, the barnacle Striatobalanus amaryllis Darwin, 1954 and the bivalve Myoforceps aristatus (Dillwyn, 1817) (also known as Lithophaga aristata and Leisolenus aristatus). The last one is also a new record for the Paraná biota.
We found 17 NIS in the estuarine area and 16 in the open coast, representing $15 \%$ and $10.5 \%$ of the hard substrate species, respectively. Three species occurred only in the former, the ascidian $S$. peregrinus, the decapod Charybdis hellerii (A. Milne-Edwards, 1867) and the polychaete $P$. cornuta, and two were exclusive in the later, the ascidians Ascidia sydneiensis Stimpson, 1885 and $A$. tenue (Table 1). In the estuarine areas, 16 and 13 NIS were reported in artificial and natural substrata, but due to the higher number of species in artificial substrata, the percentage was 17.6 and $18.6 \%$, respectively. In the open sea, we documented 14 NIS in artificial habitats and 10 NIS natural ones, representing 12.2 and $8.3 \%$, respectively.

Of the 19 NIS, 15 were found in field surveys carried out since December/2012 (Appendix 1). Except for the barnacle B. trigonus and the ascidian $S$. peregrinus, new sites of occurrence are reported for all species, expanding their local distribution range. There were NIS in all surveyed sites, ranging between three and eight species per site. The places with more NIS were artificial substrata, the Techint pier, with eight NIS, the artificial reefs (ARs1) and Ponta do Poço marina, with six species each. Vedado Rock had five species, and all other sites had three or four NIS each (Appendix 2). 


\section{DISCUSSION}

Our results suggest substantial spread of NIS into natural habitats, more pronounced in the estuarine areas. There is no temporal data to state that the NIS were previously restrict to artificial habitats and then escaped to natural ones. However, due to the well known role of artificial habitats in the establishment of new introductions, this is probably the pathway of NIS spread. The percentage of non-indigenous species was the same between natural and artificial substrata in the Paraná coast, and all the established and invasive species found occurred in both substrates. In the estuarine areas, almost all NIS occur independently of the type of substrata. The main difference between the artificial and natural substrata was the total number of species, which was higher in artificial substrata. Indeed, PEC has some islands, but the hard substrata environment is dominated by man-made structures. This, summed to port and industrial activities, aquaculture and an intense small-scale boating, provide a suitable habitat for bioinvasion.

Similar results were found in the Ilha Grande Bay, southeastern Brazil, where there were more species in artificial substrata but there, the percentage of NIS was higher in natural substrata (16\%) than in artificial ones (13\%) (IGNACIO et al. 2010). It is interesting to note that the two studies carried out in Brazil (the present study and IGNACIO et al. 2010) comparing well-established natural and artificial hard communities are the only ones, to our knowledge, that reveal such a great spread of NIS to natural substrata. A review study showed that in North America 90\% of all alien species were found on artificial substrata and those had more NIS than natural ones (Ruiz et al. 2009). In fouling communities in Australia, the richness of NIS was 1.5 - 2.5 times greater on pontoons or pilings than on rocky reefs (GLASBY et al. 2007). Two surveys focused on ascidians showed more NIS in artificial than in natural substrata, with the colonization of natural rocky habitats by two alien species both in Italy (AIroLDI et al. 2015) and in Canada (SIMKANIN et al. 2012).

As expected, the proportion of NIS was higher in the estuarine areas in comparison to the open ocean. However, both environments comprise almost the same absolute number of NIS and share most of them, revealing that alien species are reaching places far from the estuarine conditions, supposedly colonized first during the invasion process. In contrast to our results, a study in California revealed that the estuary was far more invaded than the adjacent open coast, both in terms of absolute numbers of NIS (58 vs. 8 , respectively) and proportion (11\% vs. $1.5 \%$, respectively) (WAsson et al. 2005). Although less pronounced, the same trend of higher percentage of NIS in estuarine environments than at open coast occurred in Argentina (11\% vs. 5\%) and in the Netherlands (7\% vs. $4 \%$ ) (see PreisLer et al. 2009). In New Hampshire, in contrast, coastal and estuarine habitats had equal absolute numbers of NIS and similar percentages (21\% and 19\%) (see Preisler et al. 2009).

There are many factors influencing the different results between regions. Survey methods differed between studies, for example, with those in California, Netherlands and Paraná representing an extensive search for years, while those in Argentina and New Hampshire consisted of more focused, shorter efforts (WAsson et al. 2005, Preisler et al. 2009). Also, one of the main factors influencing the distribution of NIS is the availability of propagule in the area. In Paranaguá, a study testing the colonization of invertebrates on recruitment plates close to the port area revealed that $16 \%$ of colonizing species were non native (CAngussu et al. 2010). The same kind of study was conducted in the nearshore continental shelf of Paraná,with 23\% of non native species, suggesting a high propagule supply, even in the open coast (BumbeER \& Rocha 2012). This may be due the direct influence of continental drainage from the estuaries, one of the main processes of larval dispersal, and the contribution of local vectors for the spread of marine introduced species, such as fishing and recreational boat hulls. These boats travel back and forth the estuaries and the open sea, thereby connecting coasts, islands and marinas, thus increasing the probability that NIS will be transported to an increasing number of habitats (MurRaY et al. 2011).

Anthropogenic structures may also enhance the propagule pressure, since they provide substrata for colonization and can act as stepping stones for NIS (Glasby et al. 2007, Tyrell \& Byers 2007). In the shallow inner continental shelf of Paraná $(<30$ $m$ deep), approximately 2,000 units of artificial reefs, made of concrete blocks have been placed between the islands of Currais and Itacolomis and another 6,000 between the islands of Currais and Galheta (BRANDINI 2013). The region is naturally poor in hard bottom habitats and these artificial reefs increased habitat availability for benthic organisms. Considering only the open sea, our results showed that there were more NIS in artificial substrata than in natural ones. Even so, the proportional number of NIS was also high in natural substrata. Whether the artificial reefs have influenced in the spread of NIS to coastal islands remains an open question, since there is no data prior to the deployment of the structures. Moreover, the extent to which different artificial substrata influence the bioinvasion process is controversial. VAZ-PINTO et al. (2013) provided evidence that substratum-specific features influence the initial colonization of NIS, but other processes/ species interactions were more important later on succession. Nevertheless, while it is widely accepted that artificial structures are important to NIS establishment and subsequent spread, there is still no pattern of native and introduced species richness associated with substratum type (Glasby et al. 2007, Tyrell \& Byers 2007, Ignacio et al. 2010, VAz-Pinto et al. 2013).

The spread to natural habitats by NIS is a fundamental component of the invasive capacity of a species (RicHARDSON et al. 2000). However, most bioinvasion studies are restricted to artificial substrata, and little is known about the spread of NIS to natural habitats, mainly in the open sea. Sampling bias towards artificial substrates make it difficult to understand the rate of species spread and bioinvasion impacts. This is a smaller problem in places where the biota has been intensely surveyed and new introductions of species can be easily recognized, like some sites in North America 
and Europe. But in South America, where there is a huge gap of biodiversity inventories of pristine environments, estimating bioinvasion numbers and impact is a certain challenge (РҮร̌EK et al. 2008, NuÑEZ \& PAUCHARD 2010). This is an important marine biosecurity issue, since programs developed for the detection, monitoring and control of marine invasion are based on general models that may not fit each region needs (Nuñez \& Pauchard 2010).

Our study contributes to the knowledge of bioinvasion in the Southwestern Atlantic coast. Here we have shown that anthropogenic habitats and estuaries are not unique in supporting NIS, which may be also frequent in natural substrates and open sea. Such spread of NIS may become common in other regions as the supply of propagules increases with human activities. In addition to species transfers, these activities would result in the creation of artificial structures, providing hard substrata that may be more vulnerable to colonization. Surveys restricted to artificial hard substrata (e.g., a rapid assessment of docks and pilings) are efficient to detect NIS in the environment, but are not enough to understand their spread and pathways of bioinvasion. Assessments of invasion rates should focus on multiple habitat types in each ecosystem. For example, the abundance of the invasive cup coral species was assessed in both artificial and natural habitats in the Ilha Grande, Rio de Janeiro (MANGelli \& CReED 2012). The study showed that Tubastraea coccinea Lesson, 1829 was more abundant in artificial substrata, but the abundance of Tubastraea tagusensis Wells, 1982 did not differed between substrata. Although the present study fills an important gap in the knowledge of NIS distribution, further studies should also include the frequency and abundance of NIS to better understand the extent and pathways of bioinvasion in this region.

\section{ACKNOWLEDGMENTS}

This study is part of PREINV project, which was financed by Fundação Grupo Boticário de Proteção à Natureza (BL2012008). We also used data from the project Currais (0927 20112) and Rebimar, financed by Petrobras. We are grateful for the support provided by Marbrasil Association and by the Graduate Program in Ecology and Conservation - UFPR, the doctoral scholarship from CAPES to JAB, and a research grant from CNPq to RMR (305201/2014-0). We want to thank Robin Loose for assistance in field work, and two anonymous reviewers for their contribution. We also thank Maria Angélica Haddad (Cnidaria), Luiz Ricardo de Simone and Daniel Cavallari (Mollusca) and Isabela Monteiro Neves (Tunicata), who helped with the identification of species.

\section{LITERATURE CITED}

Airoldi L, Turon X, Perkol-Finkel S, Rius M (2015) Corridors for aliens but not for natives: effects of marine urban sprawl at a regional scale. Diversity and Distributions 21: 755-768. doi: 10.1111/ddi.12301
Altvater L, Coutinho R (2015) Colonisation, competitive ability and influence of Stragulum bicolor van Ofwegen and Haddad, 2011 (Cnidaria, Anthozoa) on the fouling community in Paranaguá Bay, Southern Brazil. Journal of Experimental Marine Biology and Ecology 462: 55-61. doi. 10.1016/j. jembe.2014.10.007

BRANDINI F (2013) Marine biodiversity and sustainability of fishing resources in Brazil: a case study of the coast of Paraná state. Regional Environmental Change 14(6): 2127-2137. doi: 10.1007/s10113-013-0458-y

Bumbeer JA, Rocha RM (2012) Detection of introduced sessile species on the near shore continental shelf in southern Brazil. Zoologia 29(2): 126-134. doi: 10.1590/S198446702012000200005

Bulleri F, Chapman MG (2010) The introduction of coastal infrastructure as a driver of change in marine environments. Journal of Applied Ecology 47: 26-35.

Cangussu lC, Altvater L, Haddad MA, Cabral AC, Linzmeier H, Rocha RM (2010) Substrate type as a selective tool against colonization by non-native sessile invertebrates. Brazilian Journal of Oceanography 58(3): 219-231.

Carlton JT, Newman WA, Pitombo FB (2011) Barnacle Invasions: Introduced, Cryptogenic, and Range Expanding Cirripedia of North and South America, p. 159-214. In: GaLIL BS, CLARK PF, Carlton JT (Eds.) In the Wrong Place - Alien Marine Crustaceans: Distribution, Biology and Impacts. Dordrecht, Springer, Series in Invasion Ecology, XVI+716p. doi: 10.1007/978-94-007-0591-3

ConNell SD (2001). Urban structures as marine habitats: an experimental comparison of the composition and abundance of subtidal epibiota among pilings, pontoons and rocky reefs. Marine Environmental Research 52: 115-125.

Dafforn KA, Glasby TM, Johnston EL (2012) Comparing the invasibility of experimental "reefs" with field observations of natural reefs and artificial structures. PLoSOne 7(5): e38124. doi: 10.1371/journal.pone.0038124

Frigotto SF, Serafim-Junior M (2007). First record of Charybdis hellerii (Milne Edwards, 1867) (Crustacea) in the littoral State of Paraná. Estudos Biologicos 29(67): 227-230.

Glasby TM, Connell SD, Holloway M, Hewitt C (2007) Nonindigenous biota on artificial structures: could habitat creation facilitate biological invasions? Marine Biology 151: 887-895.

Hendler G, Migotto AE, Ventura CRR, Wilk L (2012) Epizoic Ophiothella brittle stars have invaded the Atlantic. Coral Reefs 31(4): 1005. doi: 10.1007/s00338-012-0936-6

IAP (2015) Portaria $\mathbf{n}^{\circ}$ 059, 15 de abril de 2015. Reconhece como espécies exóticas invasoras no estado do Paraná as espécies relacionadas nos Anexos 1 (Plantas), 2 (Vertebrados) e 3 (Invertebrados) da presente Portaria. Curitiba, Instituto Ambiental do Paraná, available online at: http://www.iap.pr.gov. br/uploads/0aOfca82-a800-ee6d.pdf [Accessed: 14/07/2015]

Ignacio BL, Julio LM, Jungueira AOR, Ferreira-Silva MAG (2010) Bioinvasion in a Brazilian Bay: filling gaps in the knowledge 
of Southwestern Atlantic biota. PLoS ONE 5(9): e13065. doi: 10.1371/journal.pone.0013065

KlôH ADS, Farrapeira CMR, Rigo APR, Rocha RM (2013) Intertidal native and introduced barnacles in Brazil: distribution and abundance. Marine Biodiversity Records 6: e102. doi: $10.1017 /$ S1755267213000766

Kremer LP, Metri R, Rocha RM (2011) Description of Sidneioides peregrinus sp. nov. (Tunicata: Ascidiacea: Polyclinidae): a possible exotic species in the Atlantic Ocean. Zoologia 28(6): 784-788. doi: 10.1590/S1984-46702011000600012

Lambert G, Lambert C (2003) Persistence and differential distribution of nonindigenous ascidians in harbors of the Southern California Bight. Marine Ecology Progress Series 259: 145-161.

Lana PC, Marone E, Lopes RM, Machado EC (2001) The subtropical estuarine complex of Paranaguá Bay, Brazil. Ecological Studies 144: 131-145.

LOPES RM (2009) Informe sobre as espécies exóticas invasoras marinhas no Brasil. Brasília, Ministério do Meio Ambiente, Série Biodiversidade 33, 439p.

Mangelli TS, Creed JC (2012) Análise comparativa da abundância do coral invasor Tubastraea spp. (Cnidaria, Anthozoa) em substratos naturais e artificiais na Ilha Grande, Rio de Janeiro, Brasil. Iheringia, Série Zoologia, 102(2): 122-130. doi: 10.1590/S0073-47212012000200002

Murray CC, Pakhomov EA, Therriault TW (2011). Recreational boating: a large unregulated vector transporting marine invasive species. Diversity and Distributions 17: 1161-1172.

Neves CS, Rocha RM (2008) Introduced and Cryptogenic Species and their Management in Paranaguá Bay, Brazil. Brazilian Archives of Biology and Technology 51: 623-633.

Neves CS, Rocha RM, Pitombo FB, Roper JJ (2007) Use of artificial substrata by introduced and cryptogenic marine species in Paranaguá Bay, southern Brazil. Biofouling 23(5): 319-330. doi: 10.1080/08927010701399174

NuñEz MA, PAUChard A (2010) Biological invasions in developing and developed countries: does one model fit all? Biological Invasions 12: 707-714. doi. 10.1007/s10530-009-9517-1

Preisler RK, Wasson K, WolfF WJ, Tyrrell MC (2009) Invasions of estuaries vs. the adjacent open coast: a global perspective, $\mathrm{p}$. 587-617. In: Rilov G, Crooks JA (Eds) Biological Invasions in Marine Ecosystems: Ecological, Management, and Geographic Perspectives. Berlin, Springer-Verlag.

Pyšek P, Richardson DM, Pergil J, Jarosik V, Sixtova Z, Weber E (2008) Geographical and taxonomic biases in invasion ecology. Trends in Ecology \& Evolution 23: 237-244.

Radashevsky VI (2004). Polychaetes - Distribution Through Man's Activities. São Paulo, II Simpósio Brasileiro de Oceanografia, Instituto Oceanográfico, Universidade de São Paulo.

Richardson DM, Pysek P, Rejmánek M, Barbour MG, PAnetTa FD, West CJ (2000) Naturalization and invasion of alien plants: concepts and definitions. Diversity and Distributions 6: 93-107. Rocha RM, Kremer LP (2005). Introduced Ascidians in Paranaguá
Bay, Paraná, southern Brazil. Revista Brasileira de Zoologia 22(4): 1170-1184. doi: 10.1590/S0101-81752005000400052 Ruiz GM, Carlton JT, Grosholz ED, Hines AH (1997) Global Invasions of Marine and Estuarine Habitats by Non-Indigenous Species : Mechanisms, Extent, and Consequences. Integrative and Comparative Biology 37: 621-632.

Ruiz GM, Freestone AL, Fofonoff PW, Simkanin C (2009). Habitat distribution and heterogeneity in marine invasion dynamics: the importance of hard substrate and artificial structures, $p$. 321-332. In: WAHL M (Ed.) Marine Hard Bottom Communities: Patterns, Dynamics, Diversity and Change. Berlin, Springer.

Seebens H, Gastner MT, Blasius B (2013) The risk of marine bioinvasion caused by global shipping. Ecology Letters 16(6): 782-90. doi: 10.1111/ele.12111

Simkanin C, Davidson IC, Dower JF, Jamieson G, Therriault TW (2012). Anthropogenic structures and the infiltration of natural benthos by invasive ascidians. Marine Ecology 33(4): 499-511. doi: 10.1111/j.1439-0485.2012.00516.x

TCP (2010) Estudo de impacto ambiental: Ampliação do cais. Paranaguá, Terminal de Contêineres de Paranaguá, 100p.

Tyrell MC, Byers JE (2007) Do artificial substrates favor nonindigenous fouling species over native species? Journal of Experimental Marine Biology and Ecology 342: 54-60.

UNESCO (2014) Atlantic Forest South-East Reserves. United Nations Educational, Scientific and Cultural Organization, available online at: http://whc.unesco.org/en/list/893 [Accessed: 14/07/2015]

VAN OfWEgen LP, HADDAD MA (2011) A probably invasive new genus and new species of soft coral (Octocorallia: Alcyonacea: Clavulariidae) from Brazil. Zootaxa 3107: 38-46.

Vaz-Pinto F, Torrontegi O, Prestes ACL, Álvaro NV, Neto AI, Martins GM (2013) Invasion success and development of benthic assemblages: Effect of timing, duration of submersion and substrate type. Marine Environmental Research 94: 72-79. doi: 10.1016/j.marenvres.2013.12.007

Wasson K, Fenn K, Pearse JS (2005). Habitat differences in marine invasions of central California. Biological Invasions 7: 935948. doi: 10.1007/s1053-004-2995-2

Submitted: 31 December 2015

Received in revised form: 24 February 2016

Accepted: 15 March 2016

Editorial responsibility: Paulo da Cunha Lana

Author Contributions: JB and RMR participated equally in the preparation of this article.

Competing Interests: The authors have declared that no competing interests exist. 
Appendix 1. Depth, number of transects per sampling site and collecting dates.

\begin{tabular}{|c|c|c|c|c|c|c|c|}
\hline Sampling Sites & Depth (m) & Transects \# & Dates & Sampling Sites & Depth (m) & Transects \# & Dates \\
\hline \multirow{2}{*}{ Cobras Island } & $2-4$ & 4 & $14 / 06 / 2013$ & \multirow{6}{*}{ Currais Archipelago } & $2-4$ & 31 & $24 / 07 / 2012$ \\
\hline & $5-8$ & & $10 / 02 / 2014$ & & $5-8$ & & $18 / 12 / 2012$ \\
\hline \multirow{3}{*}{ Filhote Island } & $2-4$ & 6 & $14 / 06 / 2013$ & & & & $06 / 06 / 2013$ \\
\hline & $5-8$ & & $10 / 02 / 2014$ & & & & $17 / 12 / 2013$ \\
\hline & & & $28 / 01 / 2015$ & & & & $26 / 06 / 2014$ \\
\hline \multirow{2}{*}{ Bananas Island } & $1-3$ & 2 & $22 / 04 / 2013$ & & & & $08 / 01 / 2015$ \\
\hline & & & $28 / 01 / 2015$ & \multirow{6}{*}{ Techint Pier } & $2-4$ & 14 & $05 / 07 / 2012$ \\
\hline \multirow{4}{*}{ Baleia Rock } & $2-4$ & 6 & $05 / 06 / 2013$ & & $5-8$ & & $24 / 10 / 2012$ \\
\hline & $5-8$ & & $14 / 06 / 2013$ & & & & $14 / 07 / 2013$ \\
\hline & & & $24 / 10 / 2013$ & & & & $09 / 02 / 2014$ \\
\hline & & & $28 / 01 / 2015$ & & & & $22 / 07 / 2014$ \\
\hline \multirow{4}{*}{ Vedado Rock } & $2-4$ & 6 & $14 / 05 / 2013$ & & & & $09 / 12 / 2014$ \\
\hline & $5-8$ & & $14 / 06 / 2013$ & \multirow{2}{*}{ Ponta do Poço Marina } & $2-4$ & 4 & $10 / 02 / 2014$ \\
\hline & & & $24 / 10 / 2013$ & & $5-8$ & & $28 / 01 / 2015$ \\
\hline & & & $10 / 02 / 2014$ & \multirow{4}{*}{ ARs1 } & $\sim 18$ & 12 & $13 / 12 / 2012$ \\
\hline \multirow{5}{*}{ Galheta Island } & $2-4$ & 8 & $25 / 04 / 2013$ & & & & $13 / 06 / 2013$ \\
\hline & $5-8$ & & $05 / 06 / 2013$ & & & & $17 / 12 / 2013$ \\
\hline & & & $24 / 10 / 2013$ & & & & $07 / 01 / 2015$ \\
\hline & & & $22 / 01 / 2014$ & \multirow{5}{*}{ ARs2 } & $\sim 13$ & 16 & $14 / 02 / 2013$ \\
\hline & & & $14 / 01 / 2015$ & & & & $02 / 05 / 2013$ \\
\hline \multirow{5}{*}{ Mel Island } & $2-4$ & 7 & $30 / 04 / 2013$ & & & & $14 / 05 / 2013$ \\
\hline & $5-8$ & & $14 / 07 / 2013$ & & & & $23 / 01 / 2014$ \\
\hline & & & $24 / 10 / 2013$ & & & & $14 / 01 / 2015$ \\
\hline & & & $22 / 01 / 2014$ & & & & \\
\hline & & & $14 / 01 / 2015$ & & & & \\
\hline
\end{tabular}

Appendix 2. Benthic marine non-native species found in Paraná between July 2012 and July 2014 in eleven sites (see Fig. 1).

\begin{tabular}{|c|c|c|c|c|c|c|c|c|c|c|c|c|}
\hline \multirow{3}{*}{ Species } & \multicolumn{12}{|c|}{ Substrate } \\
\hline & \multicolumn{8}{|c|}{ Natural } & \multicolumn{4}{|c|}{ Artificial } \\
\hline & $\begin{array}{l}\text { Cobras } \\
\text { Island }\end{array}$ & $\begin{array}{l}\text { Filhote } \\
\text { Island }\end{array}$ & $\begin{array}{l}\text { Bananas } \\
\text { Island }\end{array}$ & $\begin{array}{l}\text { Baleia } \\
\text { Rock }\end{array}$ & $\begin{array}{l}\text { Vedado } \\
\text { Rock }\end{array}$ & $\begin{array}{l}\text { Galheta } \\
\text { Island }\end{array}$ & $\begin{array}{l}\text { Mel } \\
\text { Island }\end{array}$ & $\begin{array}{c}\text { Currais } \\
\text { Archipelago }\end{array}$ & $\begin{array}{l}\text { Techint } \\
\text { Pier }\end{array}$ & $\begin{array}{c}\text { Ponta do Poço } \\
\text { Marina }\end{array}$ & ARs $^{1}$ & $\mathrm{ARs}^{2}$ \\
\hline Amphibalanus amphitrite & & & & & & & & & $x$ & $x$ & & \\
\hline Amphibalanus reticulatus & & $x$ & & & $x$ & & & & & & $x$ & \\
\hline Ascidia sydneiensis & & & & & & & & & & & & $x$ \\
\hline Balanus trigonus & & & & & & & & & & & $x$ & \\
\hline Carijoa riisei & & & & $x$ & & $x$ & $x$ & $x$ & $x$ & $x$ & $x$ & $x$ \\
\hline Clavelina oblonga & & $x$ & & & $x$ & $x$ & $x$ & $x$ & & & & $x$ \\
\hline Charybdis hellerii & & & $x$ & & & & & & & & & \\
\hline Garveia franciscana & $x$ & & $x$ & & & & & & $x$ & & & \\
\hline Megabalanus coccopoma & & & & & $x$ & & & & $x$ & $x$ & & \\
\hline Myoforceps aristatus & & & & & & & & $x$ & & $x$ & $x$ & \\
\hline Ophiothela mirabilis & & & & $x$ & & $x$ & $x$ & $x$ & $x$ & & $x$ & \\
\hline Perna perna & & & & & & & $x$ & & $x$ & $x$ & & \\
\hline Stragulum bicolor & $x$ & $x$ & $x$ & $x$ & $x$ & & $x$ & & $x$ & & & \\
\hline Striatobalanus amarylis & $x$ & $x$ & & $x$ & $x$ & & & & & $x$ & $x$ & \\
\hline Styela plicata & $\mathrm{x}$ & & & & & & & & & & & \\
\hline
\end{tabular}

